A $\bigcup_{\text {publications }}$ Rec. Nat. Prod. 12:2(2018) 142-159

records of natural products

\title{
Chemical Compositions of Achillea sivasica: Different Plant Part Volatiles, Enantiomers and Fatty Acids
}

\author{
Gülmira Özek $^{\oplus 1^{*}}$, Mehmet Tekin ${ }^{\oplus 2}$, Yeşim Haliloğlu ${ }^{\oplus 1}$, \\ Kemal Hüsnü Can Başer ${ }^{\oplus 3}$ and Temel Özek ${ }^{1,4}$
}

\author{
${ }^{1}$ Department of Pharmacognosy, Faculty of Pharmacy, Anadolu University, 26470, Eskisehir, Türkiye \\ ${ }^{2}$ Department of Pharmaceutical Botany, Faculty of Pharmacy, Trakya University, 22030 Edirne, Türkiye \\ ${ }^{3}$ Department of Pharmacognosy, Faculty of Pharmacy, Near East University, Lefkoşa (Nicosia) Turkish \\ Republic of Northern Cyprus \\ ${ }^{4}$ Medicinal Plant, Drug and Scientific Research Center (AUBIBAM), Anadolu University, 26470 Eskisehir, \\ Türkiye
}

(Received March 25, 2017; Revised July 12, 2017; Accepted August 13, 2017)

\begin{abstract}
In the present work, Microsteam distillation - Solid phase microextraction (MSD-SPME) and hydrodistillation (HD) techniques were applied to obtain volatiles from Achillea sivasica, an endemic species from Turkey. GC-FID and GC/MS analysis revealed that 1,8-cineole $(22.1 \%)$ and $\alpha$-pinene $(9.3 \%)$ were the main constituents of the hydrodistilled flower volatiles. $(Z)$ - $\beta$-Farnesene $(23.9 \%)$, decanoic acid $(10.1 \%), \beta$-eudesmol $(8.0 \%)$, tricosane $(7.3 \%)$ and hexadecanoic acid $(7.2 \%)$ were the main volatiles obtained from flowers by MSDSPME. The leaf volatiles obtained by HD contained camphor (9.0\%), $\beta$-pinene $(6.9 \%), 1,8$-cineole $(6.7 \%), \alpha$-pinene (6.7\%) and $\alpha$-bisabolol $(6.6 \%)$ as the main constituents while the leaf volatiles obtained by MSD-SPME technique were rich in $(E)$-geranyl acetone $(10.5 \%)$, $(E)$ - $\beta$-ionone $(10.3 \%)$, camphor $(10.2 \%)$, 1,8-cineole $(9.6 \%)$, longiverbenone (7.9\%), $\beta$-eudesmol (7.5\%), isopropyl myristate $(6.7 \%)$ and epi- $\alpha$-bisabolol $(6.4 \%)$. The root volatiles were rich in longiverbenone $(14.1 \%)$, $(E)$-geranyl acetone $(9.3 \%)$, nonanol $(12.1 \%)$ and decanol $(12.5 \%)$. The enantiomeric distribution of the major volatile constituents was analyzed by using different $\beta$-cyclodextrin chiral columns. (1R)-(+)- $\alpha$-Pinene, (1S)-(-)- $\beta$-pinene, (4R)-(+)-limonene, (1R,3S, 5R)-(-)-trans-pinocarveol, $(1 S, 2 R, 4 S)-(-)-$ borneol, $(2 S)-(-)-\alpha$-bisabolol were detected as dominant enantiomers. The lipids extracted from the flower and leaf with Folch method and methylated with $\mathrm{BF}_{3}$ reagent contained common acids: linolenic, linoleic, hexadecanoic acids. Oleic and stearic acids were detected particularly in high amount in the flower lipids.
\end{abstract}

Keywords: Achillea sivasica; volatiles; enantiomer; fatty acids; MSD-SPME; GC/MS. C 2018 ACG Publications. All rights reserved.

\section{Introduction}

The genus Achillea L. (Asteraceae) is a perennial herb and comprise about 140 species around the worldwide [1,2]. The name of Achillea originates from the Trojan warrior Achilles, who used yarrow (Achillea millefolium) on soldiers for wound healing [3].

\footnotetext{
* Corresponding author: E-Mail: Corresponding author: E-mail: gozek@anadolu.edu.tr; Phone:+90-222-3350580; Fax:+90-222-3350750
}

The article was published by ACG Publications www.acgpubs.org/RNP @ March-April 2018, EISSN:1307-6167 DOI: http://doi.org/10.25135/rnp.11.17.03.024 
Achillea species are used as traditional treatment for analgesic purposes at abdominal pain, menstrual pain, headache, rheumatics pain. They are used for ulcer, appetizing, carminative, diuretic and against fleas as insecticidal [4-7] A. millefolium reviewed by German Commission E advert to its astringent, cholerethic, antibacterial, antispasmodic effects [8]. In literature survey, the essential oil of Achillea species showed antioxidant [9-11], antimicrobial and antifungal [12-16], antimelanogenesis [17], antiinflammatory and for healing $[18,19]$, cytotoxic and insecticidal activities [20-22].

The survey of previous studies on essential oil contents revealed that main (major) volatile components of Achillea species are oxygenated monoterpenes, mostly 1,8-cineole and camphor. Essential oil contents from literature survey are summarized in Table 1.

Table 1. Essential oil compositions of Achillea species (literature survey).

\begin{tabular}{|c|c|c|c|}
\hline Species & Main compound, $\%$ & Location & Ref. \\
\hline $\begin{array}{l}\text { A. abrotanoides } \\
\text { (Vis.) Vis }\end{array}$ & 1,8-cineole +camphor 32.7 & & [23] \\
\hline \multirow[t]{2}{*}{ A. aleppica DC. } & camphor $34,1,8$-cineole $20, p$-cymene 14.2 & Turkey (Elazig /Hazar) & [24] \\
\hline & camphor $33,1,8$-cineole $26.1, \alpha$-pinene 4 & Turkey (Elazig/Keban) & {$[24]$} \\
\hline A. asplenifolia Vent. & $\begin{array}{c}\beta \text {-caryophyllene } 17.6 \text {, germacrene-D } 15.6 \\
\text { chamazulene } 13.3\end{array}$ & Yugoslavia & {$[25]$} \\
\hline \multirow[t]{5}{*}{ A. biebersteinii Afan. } & $\begin{array}{c}\beta \text {-eudesmol 19.1, piperitone } 9.2 \text {, camphor } 4.2 \\
\text { borneol } 3.3\end{array}$ & $\begin{array}{l}\text { Turkey (Ankara Beynam } \\
\text { forest) }\end{array}$ & [26] \\
\hline & piperitone 31.1 , camphor $12.5,1,8$-cineole 10.9 & Turkey (Erzurum) & {$[27]$} \\
\hline & 1,8-cineole, 30.6 piperitone, 28.9 , camphor, 11.7 & Turkey (Agri Mountain) & [28] \\
\hline & 1,8-cineole 31.1 , camphor 14.4 & $\begin{array}{l}\text { Turkey (Dumluca- } \\
\text { Sivas) }\end{array}$ & {$[28]$} \\
\hline & 1,8 cineole 38.1 , camphor 23.6 , borneol 5.8 & Turkey (Erzurum) & [29] \\
\hline A. biserrata $\mathrm{M}$. Bieb. & $\begin{array}{c}\text { camphor 36.8, 1,8-cineole } 19.4 \text {, camphene } 16.4 \text {, } \\
\text { artemisia alcohol } 14.3\end{array}$ & $\begin{array}{l}\text { Turkey (Gümüşhane, } \\
\text { Trabzon) }\end{array}$ & {$[13]$} \\
\hline $\begin{array}{l}\text { A. boissieri Hausskn. } \\
\text { Ex Boiss }\end{array}$ & $\begin{array}{c}\text { 1,8-cineole } 27.4 \text {, camphor } 25.3 \text {, caryophyllene } \\
\text { oxide } 4.60\end{array}$ & Turkey (Elbistan) & {$[30]$} \\
\hline \multirow[t]{2}{*}{ A. clavennae L. } & camphor 29.5, myrcene $5.5,1,8$-cineole 5 & $\begin{array}{l}\text { Montenegro (Velebit } \\
\text { Mountain, Dalmaçya) }\end{array}$ & {$[31]$} \\
\hline & $\begin{array}{c}\text { camphor } 46.9,1,8 \text {-cineole } 43.9 \text {, caryophyllene } \\
\text { oxide } 2.25\end{array}$ & $\begin{array}{l}\text { Serbia (Stara Planina } \\
\text { eastern) }\end{array}$ & [32] \\
\hline A. collina Becker & $\begin{array}{l}\text { chamazulene } 30-67 \text { in flower, } \beta \text {-caryophyllene } 2 \text { - } \\
17, \beta \text {-cubebene } 1-9\end{array}$ & & {$[33]$} \\
\hline A. coarctata Poir. & 1,8-cineole 20.1 , camphor 15.6 , viridiflorol 11.8 & Turkey (South Anatolia) & [34] \\
\hline A. cretica $\mathrm{L}$. & $\begin{array}{c}\text { caryophylladienol-II } 13.4, \beta \text {-maaliene } 6.1, \\
\text { neointermedeol } 6.0\end{array}$ & Turkey (Muğla/Datça) & {$[35]$} \\
\hline A. cucullata Bornm. & camphor $32.6,1,8$-cineole 29.2 , isoborneol 3,5 & Turkey (Malatya) & [24] \\
\hline A.distans W.\&K. & 1,8-cineole 16.8, trans-thujone 9.8, sabinene 8.2 & & [36] \\
\hline A. eriophora DC. & 1,8-cineole $34, \alpha$-pinene $7.6, \beta$-pinene 6.2 & Iran (Badjgah) & [37] \\
\hline A. falcata L. & 1,8-cineole $14-24$, camphor 4-24, $\alpha$-pinene $2-12$ & $\begin{array}{l}\text { Turkey (Antalya-Elmali, } \\
\text { Antalya-Anamur) }\end{array}$ & [38] \\
\hline A. filipendulina Lam. & $\begin{array}{c}1,8 \text { cineole } 22.9,2,7 \text { dimethyl octa-3,6dien-2-ol, } \\
21.9, \text { borneol } 8.1\end{array}$ & Turkey (Diyarbakır) & [11] \\
\hline $\begin{array}{l}\text { A. formosa (Boiss.) } \\
\text { Sch. Bip. subsp. } \\
\text { amanica (Rech. f) }\end{array}$ & $\begin{array}{l}\text { borneol } 12.8, \text { hexadecanoic acid } 11.6 \text {, } \\
\text { caryophyllene oxide } 5.5\end{array}$ & Turkey (Osmaniye) & [39] \\
\hline \multicolumn{4}{|l|}{ Ehrend \& Y.P. Guo } \\
\hline $\begin{array}{l}\text { A. goniocephala } \\
\text { Boiss. et Bal. }\end{array}$ & camphor $32.6,1,8$-cineole 23.2 & $\begin{array}{l}\text { Turkey (Kahraman } \\
\text { Maraş: Göksun- } \\
\text { Yeşilkent) }\end{array}$ & [40] \\
\hline $\begin{array}{l}\text { A. gypsicola Hub- } \\
\text { Mor. }\end{array}$ & camphor 40.2, 1,8-cineole 22, piperitone 11.3 & Turkey (Çorum) & [41] \\
\hline $\begin{array}{l}\text { A. hamzaoglui } \\
\text { Arabaci \& Budak }\end{array}$ & 1,8-cineole 24.1, linalool 12.2, camphor 6.7 & Turkey (Kirşehir) & [42] \\
\hline $\begin{array}{l}\text { A. holosericea Sibth } \\
\text { \& Sm. }\end{array}$ & 1,8-cineole 47.4 , camphor 23.5 , borneol 17.11 & Macedonia (Ohrid) & [32] \\
\hline A. ketenoglui $\mathrm{H}$. & 1,8-cineole 13.8, borneol 14.1, camphor 13.4 & Turkey (Ankara) & [43] \\
\hline
\end{tabular}




\begin{tabular}{|c|c|c|c|}
\hline Species & Main compound, $\%$ & Location & Ref. \\
\hline Duman & $\begin{array}{c}\text { terpinen-4-ol 14.5, trans-sabinene hydrate } 10.9, \\
\text { cis-sabinene hydrate } 5.9\end{array}$ & Turkey (Eskişehir) & \\
\hline A. kotschyi & 1,8-cineole 22.5 , caryophyllene oxide $10.1, p$ - & Yozgat & {$[42]$} \\
\hline Boiss.subs. kotschyi & cymene 8.4 & & \\
\hline \multirow[t]{3}{*}{ A. ligustica All. } & leaf: 4-terpineol 19.3 , carvone $8.9, \gamma$-terpinene 7.2 & Sicily (Liguria) & [44] \\
\hline & $\begin{array}{l}\text { flower: 4-terpineol 12.0, carvone } 10.0 \text {, } \\
\text { } \beta \text {-phellandrene } 5.4\end{array}$ & Sicily (Liguria) & [44] \\
\hline & santolina alcohol 21.1, borneol 15.0 & Italy (Sardina) & {$[45]$} \\
\hline A. lingulata $\mathrm{W} \& \mathrm{~K}$. & $\begin{array}{c}\text { T-cadinol } 22.4 \text {, caryophyllene oxide } 16.6 \text {, } \\
\alpha \text {-bisabolone oxide } 12.79\end{array}$ & Macedonia (Ohrid) & {$[32]$} \\
\hline A. lycaonica Boiss \& & camphor 43.19 & & {$[46]$} \\
\hline Heldr. & $\begin{array}{c}\text { trans-sabinene hydrate } 9.3 \text {, terpinen- } 4 \text {-ol } 9 \\
\text { caryophyllene oxide } 7.2\end{array}$ & Turkey (Karaman) & {$[43]$} \\
\hline \multirow[t]{6}{*}{ A. millefolium $\mathrm{L}$. } & $\begin{array}{c}\text { 1,8-cineole } 6.6, \delta \text {-cadinol } 6.2 \text {, caryophyllene } \\
\text { epoxide } 5.6\end{array}$ & Turkey (Erzurum) & {$[29]$} \\
\hline & $\beta$-pinene $10.6,1,8$-cineole 3.0 , borneol 0.2 & Himalaya & [47] \\
\hline & $\beta$-pinene $17.7,1,8$-cineole 15.1 , borneol 12.1 & Himalaya & {$[47]$} \\
\hline & 1,8-cineole, 5.2 germacrene D 14.1 & Iran & {$[48]$} \\
\hline & $\begin{array}{c}\text { artemisia ketone } 14.9 \text {, camphor } 11,6 \text {, linalyl } \\
\text { acetate } 11.5\end{array}$ & & {$[17]$} \\
\hline & $\begin{array}{c}\beta \text {-pinene } 32.6, \beta \text {-caryophyllene } 16.5 \text {, sabinene } \\
11.5\end{array}$ & $\begin{array}{l}\text { River Nisava Eastern } \\
\text { Serbia }\end{array}$ & {$[32]$} \\
\hline Achillea millefolium & 1,8 cineole 24.6 , camphor $16.7, \alpha$-terpineol 10.2 & Turkey (Sivas/Kizildağ) & {$[14]$} \\
\hline $\begin{array}{l}\text { subsp. millefolium } \\
\text { Afan. }\end{array}$ & $\begin{array}{c}\text { 3-cyclohexen-1-one } 21.6, \text { linalool 14.3, 1,8- } \\
\text { cineole } 12.7\end{array}$ & Turkey (Elaziğ) & [49] \\
\hline $\begin{array}{l}\text { A. millefolium subs. } \\
\text { elborsensis }\end{array}$ & chamazulene 48.9 , isoborneol 10.2, camphor 9.5 & & {$[50]$} \\
\hline $\begin{array}{l}\text { A. monocephala Bois. } \\
\text { Bal. }\end{array}$ & camphor 30.2 , borneol 15.6 & $\begin{array}{c}\text { Turkey } \\
\text { (Çukurova/Adana) }\end{array}$ & {$[51]$} \\
\hline & camphor 34.6 , borneol 23.6, 1,8-cineole 12.4 & Çukurova/Adana & {$[51]$} \\
\hline $\begin{array}{l}\text { A. multifida (DC.) } \\
\text { Boiss. }\end{array}$ & $\begin{array}{c}\alpha \text {-thujone } 60.9, \beta \text {-thujone } 9.1 \text {, sabinene } 4.1 \text {, } \\
\text { camphor } 3.7\end{array}$ & Turkey (Uludağ/Bursa) & {$[12]$} \\
\hline $\begin{array}{l}\text { A. nobilis L. subsp. } \\
\text { neilreichii (Kerner) }\end{array}$ & fragranyl acetate 32 , fragranol 24, 3-eudesmol 8 & Turkey (Beyşehir) & {$[10]$} \\
\hline $\begin{array}{l}\text { A. odorata L. var. } \\
\text { microphylla (Willd.) } \\
\text { Willk }\end{array}$ & camphor $26.3,1,8$-cineole $17.8, \alpha$-pinene 12.5 & Algeria & {$[52]$} \\
\hline $\begin{array}{l}\text { A. odorata L. subsp. } \\
\text { pectinata (Lamk) var } \\
\text { microphylla (Wild.) } \\
\text { Wilk. }\end{array}$ & camphor $22.9,1,8$-cineole $15.7, \alpha$-pinene 11.3 & Algeria & {$[52]$} \\
\hline A. oligocephala DC & 1,8-cineole $18.6, \alpha$-terpineol 6.8 , linalool 6.0 & Turkey (South Anatolia) & [34] \\
\hline \multirow[t]{4}{*}{$\begin{array}{l}\text { A. phrygia } \text { Boiss. \& } \\
\text { Bal. }\end{array}$} & $\begin{array}{l}\text { cis-piperitol 11.2, trans- } p \text {-menth-2-en-1-ol 11.0, } \\
\text { cis- } p \text {-menth-2-en-1-ol 7.2, 1,8-cineole 9.1 }\end{array}$ & $\begin{array}{c}\text { Turkey } \\
\text { (Seyitgazi/Eskişehir) }\end{array}$ & {$[53]$} \\
\hline & $\begin{array}{l}\text { cis-piperitole } 31.2 \text {, trans-p-menth-2-en-1-ol 14.7, } \\
\text { cis-p-menth-2-en-1-ol 9.9, 1,8-cineole } 9.9\end{array}$ & Turkey (Alpu/Eskişehir) & {$[53]$} \\
\hline & camphor 14.5, linalool 9.9 & $\begin{array}{l}\text { Turkey (Mihalliççik/ } \\
\text { Eskişehir) }\end{array}$ & {$[53]$} \\
\hline & $\begin{array}{c}\text { camphor 35.6, 2-furaldehyde } 16.6,1,8 \text {-cineole } \\
10.1\end{array}$ & $\begin{array}{l}\text { Turkey (Nevşehir, } \\
\text { Avanos) }\end{array}$ & {$[54]$} \\
\hline $\begin{array}{l}\text { A. salicifolia } \text { subsp. } \\
\text { salicifolia }\end{array}$ & camphor $55.3,1,8$-cineole 22.8 , camphene 3.2 & Turkey (Göle/Ardahan) & {$[13]$} \\
\hline A. sieheana Stapf. & $\begin{array}{c}\text { camphor } 43.3 \text {, artemisia ketone } 25.9,1.8 \text {-cineole } \\
6.3 \text {, camphene } 4.8\end{array}$ & $\begin{array}{l}\text { Turkey (eveli, } \\
\text { Sindelhöyuk, Kayseri) }\end{array}$ & {$[55]$} \\
\hline A. sieheana Stapf. & camphor $39.9,1,8$-cineole 15.5 , camphene 8.3 & Turkey (Kayseri/Develi) & {$[56]$} \\
\hline A. schischkinii Sosn. & 1,8 - cineole 31.0 , camphor 20.0 & $\begin{array}{l}\text { Turkey (Kızıldağ } \\
\text { Imranli/ Sivas) }\end{array}$ & {$[57]$} \\
\hline $\begin{array}{l}\text { A. sintenisii Hub.- } \\
\text { Mor. }\end{array}$ & $\begin{array}{c}\text { camphor } 14.8,1,8 \text { cineole } 12.9, \beta \text {-pinene } 12.8, \\
\text { borneol } 10.8\end{array}$ & Turkey (Sivas) & {$[58]$} \\
\hline
\end{tabular}




\begin{tabular}{|c|c|c|c|}
\hline Species & Main compound, $\%$ & Location & Ref. \\
\hline A. taygetea & 1,8-cineole 26.6 , camphor 24.7 & Taygetos & [59] \\
\hline Boiss\&Heldr & & & \\
\hline \multirow[t]{4}{*}{ A. teretifolia Wild. } & piperitone 21.4 , linalool $19,1,8$-cineole 6.8 & & {$[60]$} \\
\hline & $\begin{array}{c}\text { 1,8-cineole 34, camphor } 11 \text {, terpinen-4-ol 8.0, } \\
\alpha \text {-thujone } 5\end{array}$ & Turkey (Beyşehir) & {$[10]$} \\
\hline & 1,8-cineole 15.9 , borneol 8.1 , camphor 7.0 & $\begin{array}{l}\text { Turkey (Dumluca-- } \\
\text { Sivas) }\end{array}$ & [28] \\
\hline & $\begin{array}{c}\text { 3-cyclolohexen-1-on } 21.6 \text {, linalool } 14.3,1.8 \text { - } \\
\text { cineole } 12.7\end{array}$ & Turkey (Elaziğ) & [49] \\
\hline \multirow{4}{*}{$\begin{array}{l}\text { A. vermicularis Trin. } \\
\text { A. wilhelmsii C. } \\
\text { Koch. }\end{array}$} & 1,8-cineole 29.2, camphor 25.8 , borneol 5.2 & Turkey (Van-Muradiye) & [28] \\
\hline & camphor 39.6 & & [46] \\
\hline & $\begin{array}{c}\text { carvacrol 22.5, dihydrocarvone } 13.2 \text {, linalool } 12 \text {, } \\
\text { 1,8-cineole } 11.42\end{array}$ & $\begin{array}{l}\text { Iran (Golmakan, } \\
\text { Horasan Razavi) }\end{array}$ & {$[61]$} \\
\hline & camphor $46.6,1,8$-cineole 14.4 & Iran & [62] \\
\hline
\end{tabular}

Several methods are applied to obtain volatiles from plant material. Nowadays, simple, rapid, cheap and "green" techniques which require small amount of plant materials for analysis are in demand. There is increasing requirement for fast, safe and repeatable extraction techniques which give possibility to obtain volatiles within a short period of time. MSD-SPME technique is such a technique combining solid phase microextraction with hydrodistillation [63]. The technique gives us the possibility to obtain the volatiles in a short time from a small amount of sample [64, 65]. In this context, the tandem of MSD-SPME method with GC-FID and GC/MS techniques was applied for the analysis of the volatiles obtained from the flower, leaf and root of $A$. sivasica. MSD-SPME technique combined with GC-FID and GC/MS methods has earlier been successfully applied for the extraction of volatiles from diverse species such as Salvia rosifolia Sm. [66], Heracleum spp. [67], Prangos turcica [68], Xanthogalum purpurascens Lallem. [69] and Angelica sylvestris var. sylvestris [70].

It is known that the quality of flavoring components is dependent on enantiomeric profile. Chiral capillary GC (CC-GC) has proven to be a convenient method for characterizing enantiomeric profile of essential oils. CC-GC technique allows to differentiate natural flavors from those of synthetic origin. Chiral compounds from natural origins usually exist as one predominant optical isomer [71]. Also, the inspection of enantiomeric ratios can characterize regional differences between oils. Enantiomers are important in the determination of essential oils' sensorial properties such as smell and flavor. On the other hand, they may have different biological activity and toxicity properties. For example, $(S)-(+)$-carvone inhibited Fusarium spp. fungi and the elongation of the potato sprouts [72], while $(R)-(-)$-carvone showed important toxicity properties [73]. Variations in enantiomeric ratios of specific components which may be related to sensory characteristics, indicate substitution or adulteration, or improper storage and handling of the material. Therefore, investigation of enantiomeric distribution is important. In scope of the present work, the volatiles of $A$. sivasica were separated on chiral column to obtain information about the distribution of major enantiomeric compounds.

Hence, we aimed to carry out comprehensive investigation of the flower, leaf and root volatiles of $A$. sivasica. In scope of the present work, we attempted to evaluate the enantiomeric distribution of the major volatile constituents of $A$. sivasica by separating them on $\beta$-cyclodextrin chiral columns. In addition, we investigated the lipid composition, namely chemical composition of fatty acids which were extracted with Folch method for subsequent analysis of their composition after methylation with Boron trifluoride reagent $\left(\mathrm{BF}_{3}\right)$. So, the present work is the first comprehensive investigation of the volatiles from flower, leaf and root of Achillea sivasica using a tandem of MSD-SPME, GC-FID and GC/MS techniques. The enantiomeric distribution of major volatiles, and chemical composition of the fatty acids of $A$. sivasica were carried out for the first time. 


\section{Materials and Methods}

\subsection{Chemicals}

Boron trifluoride reagent $\left(\mathrm{BF}_{3}\right)$, hydrochloric acid, $n$-hexane (Sigma-Aldrich, Germany), calcium chloride, anhydrous sodium sulfate (Fluka, Germany), diethyl ether (JT Baker, Holland), chloroform (Sigma-Aldrich, France), methanol (Sigma-Aldrich, Poland) were of analytical grade. Standard compounds of definite enantiomeric purity were used to assess the enantiomeric ratios. $(1 R)-(+)-\alpha$-Pinene, $(1 S)-(-)-\alpha-$ pinene, $(1 R)-(+)-\beta$-pinene, $(1 S)-(-)-\beta$-pinene, $(4 R)-(+)-$ limonene, $(4 S)-(-)-$ limonene, $(4 R)-(+)$-terpinen-4-ol, $(4 S)-(-)$-terpinen-4-ol, $(1 S, 3 R, 5 S)-(+)$-trans-pinocarveol, $(1 R, 3 S, 5 R)-(-)$-trans-pinocarveol, $(1 R, 2 S, 4 R)-(+)-$

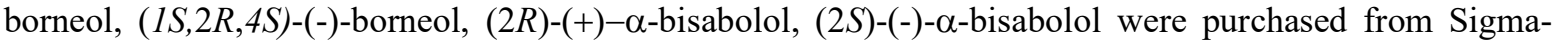
Aldrich (USA). A $\mathrm{C}_{8}-\mathrm{C}_{40} n$-alkane standard solution was purchased from Fluka (Buchs, Switzerland).

\subsection{General}

Agilent 5975 GC-MSD system (Agilent, USA; SEM Ltd., Istanbul, Turkey) was equipped with the HP-Innowax FSC column $(60 \mathrm{~m} \times 0.25 \mathrm{~mm}$ id with $0.25 \mu \mathrm{m}$ film thickness, Agilent, USA). The GC-FID analysis was carried out with capillary GC using an Agilent $6890 \mathrm{~N}$ GC system (SEM Ltd., Istanbul, Turkey). Separation of enantiomer was performed with an Agilent 5975 inert MSD with Triple-Axis Detector and Agilent 7890A GC systems (Agilent, USA; SEM Ltd., Istanbul, Turkey). The manual SPME holder (57330-U, Supelco, Bellefonte, PA) and the device for MSD-SPME system were used for MSDSPME experiments.

\subsection{Plant Material}

Plant material of A. sivasica was collected in Sivas province of Turkey: Kangal to Gürün, 8. km, calcareous area, $39^{\circ} 07^{\prime} 56.3^{\prime \prime} \mathrm{N}, 37^{\circ} 13^{\prime} 48.0^{\prime \prime} \mathrm{E}$, on June 10 , 2015. The herb was dried under the shade. Botanical identification was performed by Dr. M. Tekin (Trakya University). Voucher specimen is deposited at the Herbarium of Cumhuriyet University, Faculty of Science (CUFH) under the voucher number M. Tekin 1570.

\subsection{Hydrodistillation of Essential Oil}

A. sivasica flowers and leaves were separately subjected to hydrodistillation in a Clevenger type apparatus to yield essential oils (3 hours) [74].

\subsection{Microsteam Distillation - Solid Phase Microextraction (MSD - SPME)}

Microsteam distillation - solid phase microextraction of the volatiles was carried out using an assembly reported previously [66]. MSD-SPME involved concurrent solid-phase microextraction combined with continuous hydrodistillation of the volatiles. This method significantly makes shorter the time required for the isolation of volatiles. It should be noted that this technique allows the isolation of volatiles from a very small amount of plant material. Tandem of MSD-SPME with GC-FID and GC/MS techniques is simple, sensitive, rapid, solvent-less and non-toxic technique for analysis of the volatile compounds at microscale level. Briefly, the ground plant material $(0.3 \mathrm{~g})$ was placed in $25 \mathrm{~mL}$ round bottom flask along with $10 \mathrm{~mL}$ of water. The flask was fitted with a Claisen distillation head with plug and a condenser set up for refluxing rather than distillation. The threaded plug was used for SPME fiber assembly. A manual SPME holder (57330-U, Supelco, Bellefonte, PA) and the PDMS-DVB $65 \mu \mathrm{m}$ fiber "blue type" were used for the extraction of volatiles. Previously, the fiber was conditioned at $250{ }^{\circ} \mathrm{C}$ for $10 \mathrm{~min}$ before the experiment. After the SPME needle pierced the plug, the fiber was expressed through the needle and 
exposed to the headspace above the plant sample. Different extraction periods were applied to optimize experiment conditions. The extraction time for leaf and flower volatiles was 3, 5, 8, 10 min, while the roots were extracted for 5, 8, 10 and $15 \mathrm{~min}$. After trapping of the volatiles, the loaded SPME fiber was withdrawn into the needle, and then the needle was removed from the plug and subsequently used for GC/FID and GC/MS analyses. Thermal desorption of analytes from the fiber coating was performed by injection of the fiber in the injection port $\left(\right.$ at $\left.250^{\circ} \mathrm{C}\right)$ for $5 \mathrm{~min}$. Experiments were performed in triplicate.

\subsection{Fatty Acid Extraction and Derivatization}

The ground plant material was subjected to maceration with chloroform: methanol $(2: 1)$ at room temperature for $24 \mathrm{~h}$. The extract was filtered and the residue material was macerated twice (for $30 \mathrm{~min}$ ) more with new portions of the solvent. All filtrates were combined and half of the solvent was evaporated under vacuum in a rotary evaporator. Then, half amount of chloroform was added into the extract. The obtained extract was washed (three times) with $\mathrm{CaCl}_{2}$ solution $(0.4 \%)$ in separatory funnel. At the end of the procedure, the chloroform extract was filtered through anhydrous sodium sulfate to remove moisture, then chloroform was removed under vacuum. The dried extract was subjected to saponification. To do this, the crude extract was boiled in $\mathrm{KOH}-\mathrm{H}_{2} \mathrm{O}-\mathrm{MeOH}(1: 1: 8)$ solution for 2 hours in a refluxing system. After the saponification process, $1-2 \mathrm{~mL}$ of $n$-hexane was added to remove non-saponified compounds [75]. The fatty acids were extracted with diethyl ether after acidification of the extract with $\mathrm{HCl}$ ( $15 \%$ solution). The methylation of the free fatty acids was performed using $\mathrm{BF}_{3}$ reagent [76]. The fatty acids methyl esters were subjected to analysis with GC/MS and GC/FID techniques.

\subsection{Gas Chromatographic Analysis}

The GC/MS and GC-FID analyses were carried out with the HP-Innowax FSC column $(60 \mathrm{~m} \times 0.25$ $\mathrm{mm}$ id with $0.25 \mu \mathrm{m}$ film thickness, Agilent, USA) in conditions reported earlier [77].

\subsection{Enantioselective GC Analysis}

Enantioselective GC analyses were performed with GC/MS and GC-FID systems, Agilent 5975 inert MSD with Triple-Axis Detector and Agilent 7890A GC systems (Agilent, USA; SEM Ltd., Istanbul, Turkey) equipped with three different chiral columns to determine enantiomeric distribution of the constituents. The scanned mass spectra were recorded at $70 \mathrm{eV}$. The acquisition mass range was from $\mathrm{m} / \mathrm{z}$ 35 to $450 \mathrm{amu}$. The temperature conditions of chromatographic separation and column types are given in Table 2 .

\subsection{Identification and Quantification of Compounds}

Identification of the individual compounds was based on the following: (i) comparison of the GC/MS Relative Retention Indices (RRI) of the compounds on polar column determined relative to the retention times of a series of $n$-alkanes $\left(\mathrm{C}_{8}-\mathrm{C}_{40}\right)$, with those of authentic compounds or literature data; (ii) computer matching with commercial mass spectral libraries: MassFinder software 4.0, Adams Library, Wiley GC/MS Library (Wiley, New York, NY, USA) and Nist Library, and comparison of the recorded spectra with literature data $[78,79]$. Confirmation was also achieved using the in-house "Başer Library of Essential Oil Constituents" database, obtained from chromatographic runs of pure compounds performed with the same equipment and conditions [80]. Percent composition was obtained for each constituent on the basis of GC-FID analyses of the oils 
Table 2. Chromatographic separation conditions applied for the separation of enantiomers (experimental data).

\begin{tabular}{|c|c|c|c|}
\hline & Method 1 & Method 2 & Method 3 \\
\hline Enantiomers & $\alpha$-Pinene & Terpinen-4-ol, borneol & $\begin{array}{l}\beta \text {-Pinene, limonene, } \alpha \text { - } \\
\text { bisabolol, trans-pinocarveol }\end{array}$ \\
\hline Column & $\begin{array}{l}\text { Lipodex-G }(25 \mathrm{~m} \times 0.25 \mathrm{~mm} \\
\text { id, } 0.125 \mu \mathrm{m} \text { film thickness }) \\
(6-\text { methyl-2,3-pentyl- } \gamma- \\
\text { cyclodextrin }),(60 \% \text { in } \\
\text { polysiloxane PS086) }\end{array}$ & $\begin{array}{l}\mathrm{Rt}^{\mathrm{TM}}-\beta \text {-DEXse }(25 \mathrm{~m} \times \\
0.32 \mathrm{~mm} \text { id, } 0.25 \mu \mathrm{m} \text { film } \\
\text { thickness) (6-tert- } \\
\text { butyldimethylsilyl-2,3- } \\
\text { diethyl- } \beta \text {-cyclodextrin) }\end{array}$ & $\begin{array}{l}\mathrm{Rt}^{\mathrm{TM}}-\beta \text {-DEXse }(25 \mathrm{~m} \times 0.32 \\
\mathrm{mm} \text { id, } 0.25 \mu \mathrm{m} \text { film } \\
\text { thickness })(6 \text {-tert- } \\
\text { butyldimethylsilyl- } 2,3- \\
\text { diethyl- } \beta \text {-cyclodextrin })\end{array}$ \\
\hline Carrier gas & Helium $(5 \mathrm{~mL} / \mathrm{min})$ & Helium (5 mL/min) & Helium (7 mL/min) \\
\hline Flow rate average & $77.985 \mathrm{~cm} / \mathrm{sec}$. & $63.943 \mathrm{~cm} / \mathrm{sec}$. & $63.943 \mathrm{~cm} / \mathrm{sec}$. \\
\hline Temperature Program & $\begin{array}{l}50 \mathrm{~min} @ 35^{\circ} \mathrm{C} ; 40^{\circ} \mathrm{C} / \mathrm{min} \text { at } \\
200^{\circ} \mathrm{C} ; 10.875 \mathrm{~min} @ \\
200^{\circ} \mathrm{C} ; \text { Total: } 65 \mathrm{~min}\end{array}$ & $\begin{array}{l}0 \min @ 40^{\circ} \mathrm{C} ; 2^{\circ} \mathrm{C} / \mathrm{min} \text { at } \\
200^{\circ} \mathrm{C} \text {; Total: } 80 \mathrm{~min}\end{array}$ & $\begin{array}{l}10 \mathrm{~min} @ 35^{\circ} \mathrm{C} ; 2{ }^{\circ} \mathrm{C} / \mathrm{min} \text { at } \\
130^{\circ} \mathrm{C} ; 57.5 \mathrm{~min} @ 130^{\circ} \mathrm{C} ; \\
40^{\circ} \mathrm{C} / \mathrm{min} \text { with } 230^{\circ} \mathrm{C} ; 2.5 \\
\min @ 230^{\circ} \mathrm{C} ; \text { Total: } 120 \mathrm{~min} .\end{array}$ \\
\hline Injection Mode & Split (10:1) & Split (40:1) & Split (40:1) \\
\hline Injection Temperature & $250^{\circ} \mathrm{C}$ & $250^{\circ} \mathrm{C}$ & $250^{\circ} \mathrm{C}$ \\
\hline
\end{tabular}

\section{Results and Discussion}

\subsection{Composition of Volatiles}

In the course of our ongoing studies on Turkish aromatic plants, we report here on the composition of endemic $A$. sivasica essential oil, determined by means of GC-FID and GC/MS techniques. The flower and leaf oils were obtained with conventional hydrodistillation method. Yields of the essential oils of $A$. sivasica were calculated on moisture free basis: flower $(0.048 \%)$ and leaf $(0.036 \%)$. Additionally, the volatiles of the flower, leaf and root were obtained with modern rapid MSD-SPME technique and subsequently analyzed with GC-FID and GC/MS. Table 3 lists the detected compounds with their RRI values, relative percentages and methods of identification. 1,8-Cineole $(22.1 \%)$ and $\alpha$-pinene $(9.3 \%)$ were found to be the main constituents of the flower volatiles obtained with HD. In the flower volatiles obtained with MSD-SPME, $(Z)-\beta$-farnesene (23.9\%), decanoic acid (10.1\%), $\beta$-eudesmol $(8.0 \%)$, tricosane $(7.3 \%)$ hexadecanoic acid (7.2\%), 1,8-cineole (5.3\%), epi- $\alpha$-bisabolol $(4.9 \%)$ and germacrene D $(4.7 \%)$ were found as the main constituents. Hence, MSD-SPME technique was more sensitive in trapping flower volatiles rich in sesquiterpenes.

Camphor (9.0\%), $\beta$-pinene (6.9\%), 1,8-cineole (6.7\%) $\alpha$-pinene (6.7\%), $\alpha$-bisabolol $(6.6 \%)$ and longiverbenone $(4.9 \%)$ were found to be the main constituents of the leaf volatiles obtained with HD. MSD-SPME technique trapped leaf volatiles rich in $(E)$-geranyl acetone $(10.5 \%),(E)$ - $\beta$-ionone $(10.3 \%)$, camphor (10.2\%), 1,8-cineole (9.6\%), longiverbenone (7.9\%), $\beta$-eudesmol $(7.5 \%)$, isopropyl myristate (6.7\%), epi- $\alpha$-bisabolol $(6.4 \%)$, and borneol (5.9\%). Similar to the flowers, MSD-SPME technique extracted leaf volatiles particularly rich in sesquiterpenes. The root volatiles were rich in the sesquiterpenes, longiverbenone $(14.1 \%)$ and $(E)$-geranyl acetone $(9.3 \%)$ as well as in aliphatic alcohols, nonanol $(12.1 \%)$ and decanol (12.5\%). 
Table 3. A. sivasica essential oil composition.

\begin{tabular}{|c|c|c|c|c|c|c|c|c|c|}
\hline \multirow{3}{*}{ No } & \multirow{3}{*}{$\mathbf{R I}^{\mathbf{a})}$} & \multirow{3}{*}{$\mathbf{R R I}^{\mathbf{b})}$} & \multirow{3}{*}{ Compound } & \multicolumn{3}{|c|}{$\%^{\mathrm{c})}$} & \multirow[b]{2}{*}{ Leaf } & \multirow[b]{2}{*}{$\operatorname{oot}^{\mathrm{d})}$} & \multirow{3}{*}{ IM* } \\
\hline & & & & \multicolumn{3}{|c|}{ Flower } & & & \\
\hline & & & & HD & $\begin{array}{l}\text { MSD- } \\
\text { SPME }\end{array}$ & HD & $\begin{array}{l}\text { MSD- } \\
\text { SPME }\end{array}$ & $\begin{array}{l}\text { MSD- } \\
\text { SPME }\end{array}$ & \\
\hline 1. & 1032 & $1032[81]$ & $\alpha$-Pinene & 9.3 & 2.0 & 6.7 & 4.3 & - & e), f), g) \\
\hline 2. & 1076 & $1076[81]$ & Camphene & 0.5 & & 1.2 & & & e), f), g) \\
\hline 3. & 1118 & $1118[81]$ & $\beta$-Pinene & 3.0 & - & 6.9 & 2.1 & - & e), f), g) \\
\hline 4. & 1132 & $1132[81]$ & Sabinene & 1.7 & & 1.0 & & & e), f), g) \\
\hline 5. & 1188 & $1188[81]$ & $\alpha$-Terpinene & 0.5 & & 0.2 & & & e), f), g) \\
\hline 6. & 1203 & $1203[81]$ & Limonene & - & & 1.4 & & & e), f), g) \\
\hline 7. & 1213 & $1213[82]$ & 1,8-Cineole & 22.1 & 5.3 & 6.7 & 9.6 & - & e), f), g) \\
\hline 8. & 1255 & $1256[82]$ & $\gamma$-Terpinene & 1.1 & & 0.7 & & & e), f), g) \\
\hline 9. & 1280 & $1278[82]$ & $p$-Cymene & 0.5 & & 0.2 & & & e), f), g) \\
\hline 10. & 1290 & $1290[81]$ & Terpinolene & 0.2 & & 0.2 & & & e), f), g) \\
\hline 11. & 1474 & $1474[81]$ & trans-Sabinene hydrate & 2.1 & & 0.6 & & & e), f), g) \\
\hline 12. & 1480 & $1469[81]$ & $\alpha$-Longipinene & - & & 0.2 & & & e), f), g) \\
\hline 13. & 1492 & $1492[83]$ & Cyclosativene & $\mathrm{t}$ & & - & & & e), f), g) \\
\hline 14. & 1497 & $1497[81]$ & $\alpha$-Copaene & 2.8 & & 0.7 & & & e), f), g) \\
\hline 15. & 1499 & $1496[84]$ & $\alpha$-Campholene aldehyde & - & & 0.1 & & & e), f), g) \\
\hline 16. & 1506 & $1510[82]$ & Decanal & - & & 0.1 & & & e), f), g) \\
\hline 17. & 1512 & & Longicyclene & - & & $\mathrm{t}$ & & & e), f), g) \\
\hline 18. & 1532 & $1532[82]$ & Camphor & 4.1 & 1.3 & 9.0 & 10.2 & - & e), f), g) \\
\hline 19. & 1549 & $1547[85]$ & $\beta$-Cubebene & $\mathrm{t}$ & & - & & & e), f), g) \\
\hline 20. & 1556 & $1555[85]$ & cis-Sabinene hydrate & 0.6 & & - & & & e), f), g) \\
\hline 21. & 1562 & & Isopinocamphone & $\mathrm{t}$ & & - & & & e), f), g) \\
\hline 22. & 1563 & $1557[86]$ & Octanol & & - & & - & 4.1 & e), f), g) \\
\hline 23. & 1570 & & trans-p-Ment-2-en-3-ol & $\mathrm{t}$ & & - & & & e), f), g) \\
\hline 24. & 1586 & $1590[87]$ & Pinocarvone & 2.5 & & 1.3 & & & e), f), g) \\
\hline 25. & 1611 & $1611[82]$ & Terpinen-4-ol & 3.2 & 1.1 & 1.4 & - & - & e), f), g) \\
\hline 26. & 1628 & $1628[85]$ & Aromadendrene & - & & $t$ & & & e), f), g) \\
\hline 27. & 1638 & $1628[83]$ & $\beta$-Cyclocitral & - & & $\mathrm{t}$ & & & e), f), g) \\
\hline 28. & 1648 & $1648[85]$ & Myrtenal & 0.6 & & 0.5 & & & e), f), g) \\
\hline 29. & 1664 & & Nonanol & & - & & - & 12.1 & e), f), g) \\
\hline 30. & 1668 & $1666[88]$ & $(Z)$ - $\beta$-Farnesene & 2.5 & 23.9 & - & 1.2 & - & e), f), g) \\
\hline 31. & 1670 & $1671[87]$ & trans-Pinocarveol & 2.0 & & 1.6 & & & e), f), g) \\
\hline 32. & 1682 & $1687[87]$ & $\delta$-Terpineol & - & & $t$ & & & e), f), g) \\
\hline 33. & 1683 & $1685[82]$ & trans-Verbenol & 0.1 & & 0.3 & & & e), f), g) \\
\hline 34. & 1686 & & Lavandulol & 0.9 & & 0.3 & & & e), f), g) \\
\hline 35. & 1704 & & $\alpha$-Terpinyl acetate & - & $t$ & - & $t$ & & e), f), g) \\
\hline 36. & 1706 & $1706[85]$ & $\alpha$-Terpineol & 0.3 & & $\mathrm{t}$ & & & e), f), g) \\
\hline 37. & 1719 & $1719[85]$ & Borneol & 3.7 & - & 2.0 & 5.9 & - & e), f), g) \\
\hline 38. & 1726 & $1726[85]$ & Germacrene D & 3.5 & 4.7 & 2.0 & - & - & e), f), g) \\
\hline 39. & 1765 & $1755[89]$ & Geranyl acetate & 0.2 & & 0.6 & & & e), f), g) \\
\hline 40. & 1766 & & Decanol & & - & & - & 12.5 & e), f), g) \\
\hline 41. & 1733 & $1729[82]$ & Neryl acetate & - & & - & $\mathrm{t}$ & $\mathrm{t}$ & e), f), g) \\
\hline 42. & 1740 & $1740[85]$ & $\alpha$-Muurolene & 0.5 & & $\mathrm{t}$ & & & e), f), g) \\
\hline 43. & 1742 & & Geraniol & - & & $\mathrm{t}$ & & & e), f), g) \\
\hline 44. & 1755 & $1756[85]$ & Bicyclogermacrene & 0.3 & & 0.4 & & & e), f), g) \\
\hline 45. & 1773 & $1773[85]$ & $\delta$-Cadinene & 0.6 & 1.2 & 0.5 & - & - & e), f), g) \\
\hline 46. & 1776 & $1776[85]$ & $\gamma$-Cadinene & 0.3 & & $\mathrm{t}$ & & & e), f), g) \\
\hline 47. & 1786 & $1786[85]$ & ar-Curcumene & - & & $\mathrm{t}$ & & & e), f), g) \\
\hline
\end{tabular}




\begin{tabular}{|c|c|c|c|c|c|c|c|c|c|}
\hline \multirow{3}{*}{ No } & \multirow{3}{*}{$\mathbf{R I}^{\mathbf{a})}$} & \multirow{3}{*}{$\mathbf{R R} \mathbf{I}^{\mathbf{b})}$} & \multirow{3}{*}{ Compound } & \multicolumn{3}{|c|}{$\%^{\mathrm{c})}$} & \multirow[b]{2}{*}{ Leaf } & \multirow[b]{2}{*}{$\operatorname{oot}^{d)}$} & \multirow{3}{*}{ IM* } \\
\hline & & & & \multicolumn{3}{|c|}{ Flower } & & & \\
\hline & & & & HD & $\begin{array}{l}\text { MSD- } \\
\text { SPME }\end{array}$ & HD & $\begin{array}{l}\text { MSD- } \\
\text { SPME }\end{array}$ & $\begin{array}{l}\text { MSD- } \\
\text { SPME }\end{array}$ & \\
\hline 48. & 1779 & $1779[85]$ & $(E, Z)-2,4$-Decadienal & $\mathrm{t}$ & & - & & & e), f), g) \\
\hline 49. & 1804 & $1804[85]$ & Myrtenol & 1.0 & & 0.5 & & & e), f), g) \\
\hline 50. & 1830 & & Tridecanal & $\mathrm{t}$ & & - & & & e), f), g) \\
\hline 51. & 1838 & & 2-Phenylethyl acetate & $\mathrm{t}$ & & 0.4 & & & f), g) \\
\hline 52. & 1857 & $1857[85]$ & Geraniol & $\mathrm{e}$ & & 0.5 & & & e), f), g) \\
\hline 53. & 1868 & $1868[85]$ & (E)-Geranyl acetone & 0.2 & - & 1.1 & 10.5 & 9.3 & e), f), g) \\
\hline 54. & 1871 & & $\begin{array}{l}p \text {-Mentha-1,8-dien-10-yl } \\
\text { acetate }\end{array}$ & - & & $\mathrm{t}$ & & & e), f), g) \\
\hline 55. & 1882 & & $\begin{array}{l}\text { 1-Isobutyl-4-isopropyl-3- } \\
\text { isopropyl-2,2-dimethyl } \\
\text { succinate }\end{array}$ & - & - & 0.2 & 2.1 & - & g) \\
\hline 56. & 1889 & & Myrtanol & - & & 0.5 & & & e), f), g) \\
\hline 57. & 1896 & & Phenylethyl isobutyrate & 0.8 & 2.2 & - & - & - & e), f), g) \\
\hline 58. & 1900 & & Nonadecane & $\mathrm{t}$ & & - & & & e), f), g) \\
\hline 59. & 1941 & $1941[81]$ & $\alpha$-Calacorene & - & & $\mathrm{t}$ & & & e), f), g) \\
\hline 60. & 1957 & & Cubebol & 1.1 & & 0.3 & & & e), f), g) \\
\hline 61. & 1958 & $1957[81]$ & $(E)$ - $\beta$-Ionone & - & - & 0.4 & 10.3 & - & e), f), g) \\
\hline 62. & 1973 & & Dodecanol & & - & & - & 1.5 & e), f), g) \\
\hline 63. & 1988 & & $\begin{array}{l}\text { 2-Phenylethyl-2- } \\
\text { methylbutyrate }\end{array}$ & 0.3 & & - & & & f) \\
\hline 64. & 1992 & & $\begin{array}{l}\text { 2-Phenylethyl-3- } \\
\text { methylbutyrate }\end{array}$ & - & & - & $\mathrm{t}$ & $\mathrm{t}$ & g) \\
\hline 65. & 2008 & $2008[90]$ & Caryophyllene oxide & 0.2 & & 0.4 & & & e), f), g) \\
\hline 66. & 2037 & $2037[81]$ & Salvial-4(14)-en-1-one & $\mathrm{t}$ & & $\mathrm{t}$ & & & f), g) \\
\hline 67. & 2041 & & Pentadecanal & 0.3 & & 0.3 & & & e), f), g) \\
\hline 68. & 2050 & $2050[82]$ & $(E)$-Nerolidol & - & & 0.2 & & & e), f), g) \\
\hline 69. & 2052 & & Isopropyl myristate & & - & & 6.7 & - & e), f), g) \\
\hline 70 . & 2088 & & 1-epi-Cubenol & - & 2.4 & - & - & - & e), f), g) \\
\hline 71. & 2090 & & Isogymnomitrol & - & & 0.3 & & & e), f), g) \\
\hline 72. & 2094 & & 1,10-di-epi-Cubenol & 0.3 & & 0.7 & & & e), f), g) \\
\hline 73. & 2096 & $2096[81]$ & Elemol & - & & 0.3 & & & e), f), g) \\
\hline 74. & 2100 & & Heneicosane & 0.4 & & - & & & e), f), g) \\
\hline 75. & 2131 & $2131[81]$ & Hexahydrofarnesyl acetone & 0.4 & & 0.4 & & & e), f), g) \\
\hline 76. & 2144 & $2136[87]$ & Spathulenol & 1.1 & 3.8 & 0.5 & - & - & e), f), g) \\
\hline 77. & 2178 & & (Z)-3-Hexen-1-ol benzoate & - & & - & & & f), g) \\
\hline 78. & 2179 & & $\begin{array}{l}\text { 3,4-Dimethyl-5-pentyliden- } \\
2(5 \mathrm{H}) \text {-furanone }\end{array}$ & - & & 0.4 & & & f), g) \\
\hline 79. & 2187 & $2185[82]$ & T-Cadinol & 1.5 & 3.9 & 1.0 & 4.3 & - & e), f), g) \\
\hline 80. & 2192 & & Muurola-4,10(14)dien-1-ol & 0.3 & 4.2 & - & - & - & e), f), g) \\
\hline 81. & 2194 & & $\begin{array}{l}\text { 3,4-Dimethyl-5-pentylidene- } \\
\text { 2(5H)-furanone }\end{array}$ & & - & & 4.1 & - & f), g) \\
\hline 82. & 2198 & $2187[44]$ & Thymol & 0.2 & & 0.2 & & & e), f), g) \\
\hline 83. & 2209 & $2209[82]$ & T-Muurolol & - & & - & $\mathrm{t}$ & $\mathrm{t}$ & e), f), g) \\
\hline 84. & 2214 & $2214[81]$ & ar-Turmerol & - & & - & $t$ & $t$ & e), f), g) \\
\hline 85. & 2222 & $2208[91]$ & Copaborneol & 0.4 & & 0.4 & & & e), f), g) \\
\hline 86. & 2232 & $2236[85]$ & $\alpha$-Bisabolol & 4,3 & & 6.6 & & & e), f), g) \\
\hline 87. & 2255 & & $\beta$-Sinensal & 0.6 & & 0.9 & & & e), f), g) \\
\hline 88. & 2256 & $2245[82]$ & epi- $\alpha$-Bisabolol & & 4.9 & & 6.4 & - & e), f), g) \\
\hline 89. & 2257 & $2258[81]$ & $\beta$-Eudesmol & 3.9 & 8.0 & 3.6 & 7.5 & - & e), f), g) \\
\hline 90. & 2262 & $2278[92]$ & Torilenol & & 2.1 & & - & - & e), f), g) \\
\hline 91. & 2265 & & Longiverbenone & 1.0 & - & 4.9 & 7.9 & 14.14 & e), f), g) \\
\hline 92. & 2298 & $2285[83]$ & Decanoic acid & & 10.1 & & - & - & e), f), g) \\
\hline
\end{tabular}




\begin{tabular}{|c|c|c|c|c|c|c|c|c|c|}
\hline \multirow{3}{*}{ No } & \multirow{3}{*}{$\mathbf{R} \mathbf{I}^{\mathbf{a})}$} & \multirow{3}{*}{$\mathbf{R R} \mathbf{I}^{\mathbf{b})}$} & \multirow{3}{*}{ Compound } & \multicolumn{5}{|c|}{$\% \%^{c)}$} & \multirow{3}{*}{ IM* } \\
\hline & & & & \multicolumn{3}{|c|}{ Flower } & Leaf & $\operatorname{oot}^{d)}$ & \\
\hline & & & & HD & $\begin{array}{l}\text { MSD- } \\
\text { SPME }\end{array}$ & HD & $\begin{array}{l}\text { MSD- } \\
\text { SPME }\end{array}$ & $\begin{array}{l}\text { MSD- } \\
\text { SPME }\end{array}$ & \\
\hline 93. & 2300 & $2300[81]$ & Tricosane & 2.6 & 7.3 & - & - & - & e), f), g) \\
\hline 94. & 2353 & & (6S-7R)-Bisabolone & 0.5 & & 0.3 & & & e), f), g) \\
\hline 95. & 2392 & & Eudesma-4(15),7-dien-1- $\beta$-ol & - & & 0.6 & & & e), f), g) \\
\hline 96. & 2400 & $2400[81]$ & Tetracosane & 0.2 & & - & & & e), f), g) \\
\hline 97. & 2411 & & Hexyl cinnamic aldehyde & - & & 0.3 & & & g) \\
\hline 98. & 2415 & $2389[83]$ & Farnesyl acetone & - & & 0.6 & & & e), f), g) \\
\hline 99. & 2430 & & Chamazulene & $\mathrm{t}$ & & - & & & e), f), g) \\
\hline 100. & 2500 & $2500[81]$ & Pentacosane & 0.8 & & 0.4 & & & e), f), g) \\
\hline 101. & 2622 & $2606[88]$ & Phytol & - & & 2.8 & & & f), g) \\
\hline 102. & 2670 & & Tetradecanoic acid & - & & 0.7 & & & e), f), g) \\
\hline 103. & 2683 & $2655[81]$ & Benzyl benzoate & - & & 0.2 & & & e), f), g) \\
\hline 104. & 2700 & $2700[85]$ & Heptacosane & 0.6 & & 0.6 & & & e), f), g) \\
\hline 105. & 2766 & & Phenylethyl benzoate & 0.2 & & - & & & e), f), g) \\
\hline 106. & 2900 & $2900[85]$ & Nonacosane & 0.3 & & 4.5 & & & e), f), g) \\
\hline \multirow[t]{2}{*}{107.} & 2931 & $2931[81]$ & Hexadecanoic acid & 1.0 & 7.2 & 4.5 & 6.8 & 15.1 & e), f), g) \\
\hline & & & Total & 94.2 & 95.6 & 87.3 & 99.9 & 68.7 & \\
\hline
\end{tabular}

RRI: Relative retention indices; *IM: Identification Method ${ }^{\text {a) }} \mathrm{RRI}$ calculated against $n$-alkanes $\left(\mathrm{C}_{9}-\mathrm{C}_{40}\right)$ on polar HPInnowax column; ${ }^{\text {b) }}$ RRI on polar column reported in literature ${ }^{c)}$ Percent composition was obtained for each constituent on the basis of GC-FID analyses of the oils; d) The root volatiles were obtained only with MSD-SPME technique; e) Identification based on retention index of genuine compounds on the HP-Innowax column; ${ }^{\text {f) }}$ Identification on the basis of computer matching of the mass spectra from Başer, Adams, MassFinder, Wiley, and NIST libraries; ${ }^{\text {g) }}$ Tentative identified on the basis of computer matching of the mass spectra from Wiley Library.

Distribution of the major compound groups in the flower, leaf and root volatiles obtained with hydrodistillation (HD) and MSD-SPME techniques from A. sivasica is presented on Figure 1.

In hydrodistilled flower and leaf oils, oxygenated monoterpenes predominated constituting $43.6 \%$ and $26.1 \%$ of the oil, respectively. Application of MSD-SPME technique to the flowers and the leaves resulted in the extraction of oxygenated sesquiterpenes ranging from $15.8 \%$ to $29.3 \%$ and $22.8 \%$ to $36.6 \%$, respectively. In the leaf oils, total amount of the sesquiterpene hydrocarbons was scarce. It was interesting to note that MSD-SPME extracted volatiles with lower percentage of the oxygenated monoterpenes (7.7\%) from flowers. The root volatiles obtained with MSD-SPME technique were found as rich in aliphatic alcohols $(30.1 \%)$ and oxygenated sesquiterpenes $(23.4 \%)$. The monoterpenes have not been detected in the roots at all.

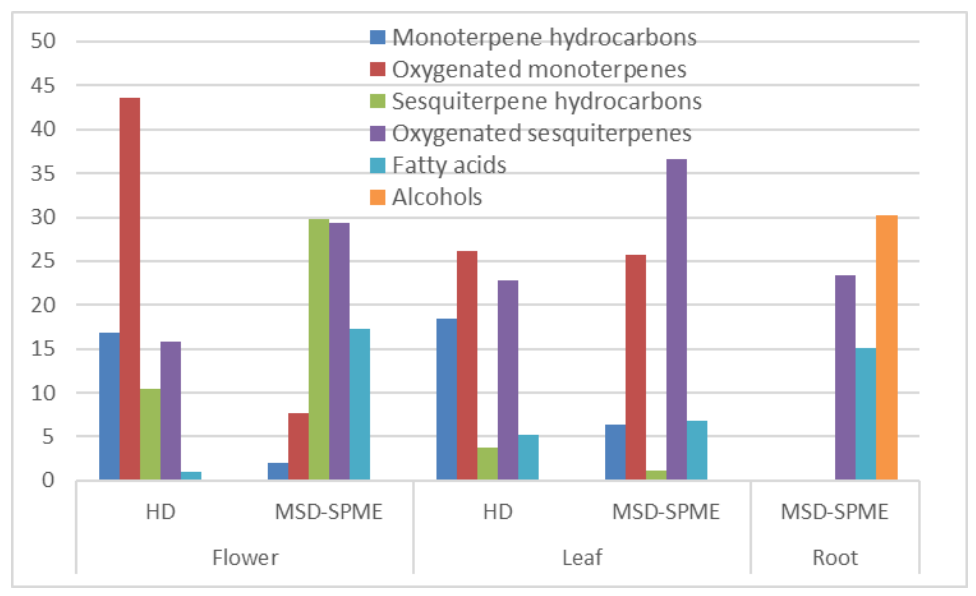

Figure 1. Distribution of the major compound groups in the flower, leaf and root volatiles obtained with hydrodistillation (HD) and MSD-SPME techniques from $A$. sivasica. 


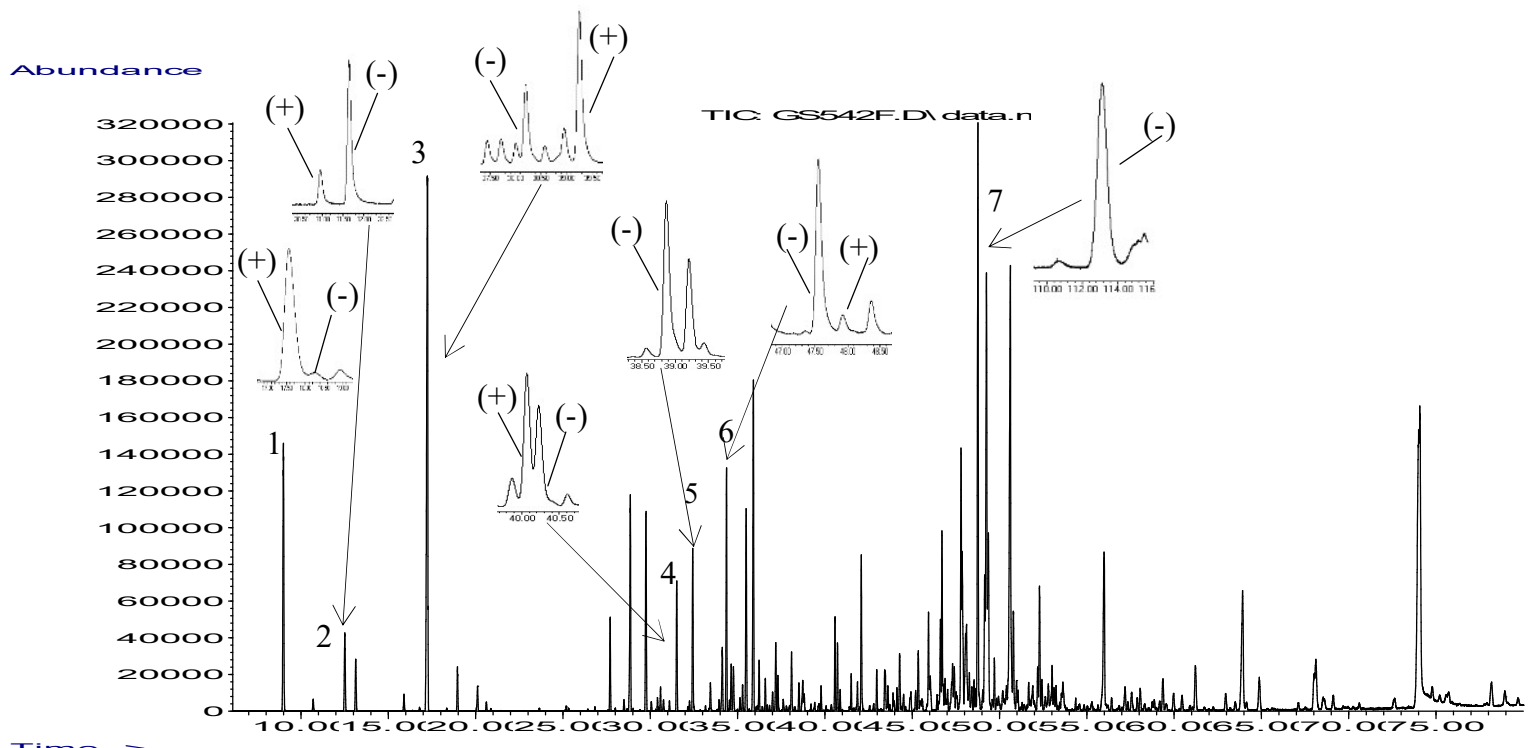

Figure 2. Representative chromatogram of $A$, sivasica flower essential oil and separation of major enantiomers: 1) $\alpha$-pinene; 2) $\beta$-pinene; 3) limonene; 4) terpinen-4-ol; 5) trans-pinocarveol; 6) borneol; 7) $\alpha$-bisabolol.

\subsection{Enantiomeric Distribution}

Stereochemical configurations of the major volatile constituents were measured by chiral GC-FID and GC/MS using three different chiral stationary phases. Chiral gas chromatography is the most popular method for the enantioselective determination of volatile phytochemicals. In scope of the present work, the essential oils of $A$. sivasica were analyzed by GC-FID and GC/MS using a split injection onto a capillary column with a stationary phase containing derivatized cyclodextrin macromolecules, achieving optimum separations of enantiomers. Before analyzing the oils, the chromatographic separation was optimized. The parameters were selected based on the information provided in the "Restek Guide to the Analysis of Chiral Compounds by GC'[93]. Representative chromatogram of separated enantiomers in the flower oil of $A$. sivasica is presented in Figure 2.

The enantiomeric ratios of certain enantiomeric compounds in the essential oil were determined, (-)$\alpha$-bisabolol and (-)-borneol were identified by $100 \%$ purity, $\alpha$-pinene, $\beta$-pinene, limonene, transpinocarveol, terpinen-4-ol compound are presented by enantiomer pairs. Percentage distribution of the enantiomeric compounds in A. sivasica oils is presented in Table5.

In the literature, there is scarce information about enantiomeric distribution of Achillea volatiles. The enantiomeric distribution of $1 S$-(-)-camphor was measured as $93.3 \%$ and $99.6 \%$ in A. falcata from two localities [38]. The enantiomeric distribution of 8 chiral constituents in A. ligustica were determined by GC-MS using two enantioselective stationary phases (DIME- $\alpha-C D$ and Lipodex-E) [94]. 
Table 4. Enantiomeric distribution of major volatiles from A. sivasica

\begin{tabular}{|c|c|c|c|}
\hline No & Enantiomer & Flower oil & Leaf oil \\
\hline 1 & $(1 R)-(+)$ - $\alpha$-Pinene & 95 & 98 \\
\hline 2 & $(1 S)-(-)-\alpha$-Pinene & 5 & 2 \\
\hline 3 & $(1 R)-(+)-\beta$-Pinene & 21 & 14 \\
\hline 4 & $(1 S)-(-)-\beta$-Pinene & 79 & 86 \\
\hline 5 & $(4 R)-(+)$-Limonene & 66 & 80 \\
\hline 6 & $(4 S)-(-)$-Limonene & 34 & 20 \\
\hline 7 & $(4 R)-(+)-$ Terpinen-4-ol & 57 & 66 \\
\hline 8 & $(4 S)-(-)-T e r p i n e n-4-o l$ & 43 & 34 \\
\hline 9 & $(1 S, 3 R, 5 S)-(+)$-trans-Pinocarveol & 7 & 21 \\
\hline 10 & $(1 R, 3 S, 5 R)-(-)-$ trans-Pinocarveol & 93 & 79 \\
\hline 11 & $(1 R, 2 S, 4 R)-(+)$-Borneol & - & - \\
\hline 12 & $(1 S, 2 R, 4 S)-(-)-$ Borneol & 100 & 100 \\
\hline 13 & $(2 R)-(+)-\alpha-$ Bisabolol & - & - \\
\hline 14 & $(2 S)-(-)-\alpha$-Bisabolol & 100 & 100 \\
\hline
\end{tabular}

\subsection{Fatty Acid Contents}

As part of our research on the phytochemical profile of essential oil bearing plants, A. sivasica was investigated also for its fatty acid composition. The present work is the first fatty acid analysis report on $A$. sivasica. Liquid-liquid extraction with subsequent methylation and GC-FID and GC/MS analyses revealed that $A$. sivasica fatty acids are comprised of 16 compounds representing $99.7 \%$ of the flower and 13 compounds representing $97.7 \%$ of the leaf lipids. 
Table 5. Fatty acid composition of $A$. sivasica

\begin{tabular}{|c|c|c|c|c|}
\hline \multirow{2}{*}{ No } & & \multirow{2}{*}{ Compound* } & Flower & Leaf \\
\hline & & & \multicolumn{2}{|c|}{$\%$} \\
\hline 1. & $\mathrm{C} 8: 0$ & Methyl octanoate & 0.1 & - \\
\hline 2 & $\mathrm{C} 10: 0$ & Methyl decanoate (=Methyl caproate) & 1.5 & - \\
\hline 3. & $\mathrm{C} 12: 0$ & Methyl dodecanoate (=Methy laurate) & 0.2 & - \\
\hline 4. & $\mathrm{C} 14: 0$ & Methyl tetradecanoate (=Methyl myristate) & 0.9 & 0.5 \\
\hline 5. & $\mathrm{C} 15: 0$ & Methyl pentadecanoate & 0.2 & 0.1 \\
\hline 6. & $\mathrm{C} 16: 0$ & Methyl hexadecanoate (=Methyl palmitate) & 22.2 & 17.3 \\
\hline 7. & C16:1 D-7 cis & (Z)-7-Methyl hexadecenoate & 0.1 & 0.2 \\
\hline 8. & C16:1 D-9 cis & (Z)-9-Methylhexadecenoate (= Methyl palmitoleate) & 0.2 & 0.2 \\
\hline 9. & $\mathrm{C} 17: 0$ & Methyl heptadecanoate & - & 0.3 \\
\hline 10. & $\mathrm{C} 18: 0$ & Methyl octadecanoate (=Methyl stearate) & 6.3 & 0.7 \\
\hline 11. & C18:1 D-9 cis & (Z)-9-Methyl octadecenoate (=Methyl oleate) & 20.9 & 3.9 \\
\hline 12. & C18:1 D-7 cis & (Z)-7-Methyl octadecenoate & 2.1 & 0.7 \\
\hline 13. & $\mathrm{C} 18: 2 \mathrm{D}-9,12 \mathrm{cis}$ & $\begin{array}{l}\text { (Z,Z)-9,12-Methyl octadecadienoate } \\
\text { (=Methyl linoleate) }\end{array}$ & 26.9 & 16.9 \\
\hline 14. & C18:1 D-9 cis & Ethyl linoleate & 2.6 & - \\
\hline 15. & C18:3 D-9,12,15 cis & Methyl linolenate & 13.2 & 56.2 \\
\hline 16. & $\mathrm{C} 20: 0$ & Methyl eicosanoate (=Methyl arachidate) & 1.2 & 0.3 \\
\hline 17. & $\mathrm{C} 22: 0$ & Methyl docosanoate (=Methyl behenate) & 1.1 & 0.4 \\
\hline & & Total & 99.7 & 97.7 \\
\hline
\end{tabular}

Seventeen fatty acids in total were identified and quantified in the flower and the leaf lipids. Fatty acids were classified as total saturated (SFA), unsaturated (UFA), monounsaturated (MUFA) and polyunsaturated (PUFA) fatty acids. Among SFAs, palmitic $(22.2 \%$ and $17.3 \%)$ acid was found to be the main constituent in the flower and the leaf lipids, respectively. It was followed by stearic acid $(6.3 \%$ and 0.7\%). Eight SFA, C8:0, C10:0, C12:0, C14:0, C15:0, C17:0, C20:0 and C22:0 were detected in smaller amounts $(0.1-1.5 \%)$. Oleic acid (20.9\% and 3.9\%) was detected as the major representative of MUFA in the flower and the leaf oils, respectively. PUFA fraction was presented by linoleic $(26.9 \%$ and $16.9 \%)$ and linolenic (13.2\% and 56.2\%) acids. Over half of the leaf lipids consisted of linolenic acid. The ratio of PUFA/SFA ranged between 1.18 and 3.7, while the ratio of UFA/SFA was 1.95 and 3.98 in the flower and the leaf oils, respectively. Fatty acid chemical contents are summarized in Table 6.

In literature, there is scarce information about fatty acids of Achillea species. Oleic (34.7\%), palmitic (23.1\%) and linoleic (20.6\%) acids were determined as the main fatty acids in A. cappadocica Hausskn, et Bornm, (whole plant) [95]. Achene fatty acids composition data for A. biebersteinii Hub.-Mor., A. bisserata M,Bieb., A. multifida (DC) Griseb., A. wilhelmsii K. Koch and A. millefolium L. were reported recently [96]. A. millefolium was characterized by low amounts of C16:0 (4\%), C18:2 (5,6\%) and C18:3 $(10,68 \%)$ [97], In contrast, $A$. sivasica was characterized by extremely high percentage of C18:3 fatty acid. A paper reported the occurrence of $24.3 \%-25.9 \%, 21.6 \%-16.8 \%$ and $41.3 \%-7.4 \%$ C18:2 and C18:3 in $A$. 
linguata, A. nobilis and A. crithmifolia, respectively [98]. A. tenuifolia L. was characterized with high contents of linoleic C18:2 (69.4\%), oleic C18:1 (14.5\%) and linolenic C18:3 (1.7\%) acids in the seed oil [99].

\section{Conclusion}

In scope of the present work, essential and fatty oils from different parts of $A$. sivasica obtained variously by conventional hydrodistillation, rapid MSD-SPME and solvent extraction (Folch method) techniques were analyzed by GC/MS and GC-FID. Enantiomeric distribution of main components was investigated with capillary enantioselective gas chromatography. This is the first contribution on chemical profile of $A$. sivasica volatiles, enantiomers, essential and fatty oils.

\section{Acknowledgments}

This work was supported by the Department of Scientific Research of Anadolu University (BAP №1504S163).

\section{ORCID}

Gulmira Ozek: 0000-0001-8908-6098

Mehmet Tekin: 0000-0002-6504-2223

Yeşim Haliloğlu: 0000-0002-2942-5358

Kemal Hüsnü Can Başer: 0000-0003-2710-0231

Temel Ozek: 0000-0003-4251-8783

\section{References}

[1] N. Çelik and A. Akpulat (2008). Achillea sivasica (Asteraceae: sect. Babounya (DC.) O. Hoffm.), a new species from Inner Anatolia, Turkey, Kew Bulletin 63, 485-489.

[2] E. Nemeth (2010). Achillea species used medicinally in Hungary, Isr. J. Plant Scie. 58, 279-289.

[3] B. Benedek and B. Kopp (2007). Achillea millefolium L. sl revisited: recent findings confirm the traditional use, Wiener Medizinische Wochenschrift. 157(13-14), 312-314.

[4] G. Honda, E. Yesilada, M. Tabata, E. Sezik, T. Fujita, Y. Takeda and T. Tanaka (1996). Traditional medicine in Turkey VI. Folk medicine in West Anatolia: Afyon, Kütahya, Denizli, Mugla, Aydın provinces, J. Etnopharmacol. 5m, 75-87.

[5] T. Fujita, E. Sezik, M. Tabata, E. Yeşilada, G. Honda, Y. Takeda, T. Tanaka and Y. Takaishi (1995). Traditional medicine in Turkey VII. Folk medicine in middle and west Black Sea regions, Econ. Bot. 49(4), 406-422.

[6] E. Sezik, E. Yesilada, M. Tabata, G. Honda, Y. Takaishi, T. Fujita, T. Tanaka and T. Yoshio (1997). Traditional medicine in Turkey. VIII. Folk medicine in East Anatolia; Erzurum, Erzincan, Agri, Kars, Igdir province, Econ. Bot. 51, 195-211.

[7] T. Baytop (1999). Türkiye'de Bitkiler ile Tedavi. Geçmişte ve Bugün, ed. B. T. Vol. 1-177. İstanbul Üniversitesi: 480.

[8] M. Blumenthal, W.R. Busse, A. Goldberg, J. Gruenwald, T. Hall, C.W. Riggins and R.S. Rister (2000). Yarrow In: Herbal medicine expanded commision e monographs, Integr. Med. Commun. Boston. 419-423.

[9] A. Akçın, A. T.A, F. Seyis, A.Y. Coban and B. Durupınar (2014). Antimicrobial and antioxidant activity of the essential oil of the Turkish endemic species Achillea phyrgia Boiss.\&Bal., J. Essent. Oil Bearing Plants. 17(2), 219-227.

[10] B. Demirci, I. Gurbuz, E. Yesilada and K.H.C. Baser (2009). Characterization and biological activity of Achillea teretifolia Willd. and A. nobilis L. subsp. neilreichii (Kerner) Formanek essential oils, Turk. J. Biol. 33(2), 129-136.

[11] N. Hasimi, S. Kizil and V. Tolan (2015). Essential oil components, microelement contents and antioxidant effects of Nepeta italica L. and Achillea filipendulina LAM., J. Essent. Oil Bear. Plants. 18(3), 678-686.

[12] K.H.C. Baser, B. Demirci, F. Demirci, S. Kocak, C. Akinci, H. Malyer and G. Guleryuz (2002). Composition and antimicrobial activity of the essential oil of Achillea multifida, Planta Med. 68(10), 941-943.

[13] A.D. Azaz, T. Arabaci and M.K. Sangun (2009). Essential oil composition and antimicrobial activities of Achillea biserrata M. Bieb. and Achillea salicifolia Besser subsp. salicifolia collected in Turkey, As. J. Chem. 21(4), 3193-3198. 
[14] F. Candan, M. Unlu, B. Tepe, D. Daferera, M. Polissiou, A. Sokmen and H.A. Akpulat (2003). Antioxidant and antimicrobial activity of the essential oil and methanol extracts of Achillea millefolium subsp millefolium Afan. (Asteraceae), J. Ethnopharmacol. 87(2-3), 215-220.

[15] C. Avancini, J.M. Wiest, Dall'Angol and G.L. Von Poser (2008). Antimicrobial activity of plants used in the prevention and control of bovine mastitis in Southern Brazil, Latin Am. J. Pharm. 27(6), 894-899.

[16] S. Barel and J. Yashphe (1989). Effect of the essential oil from Achillea fragrantissima on Escherichia coli cells, Curr. Microbiol. 19, 337-341.

[17] A. Judzentiene (2016). Atypical chemical profiles of wild yarrow (Achillea millefolium L.) essential oils, Rec. Nat. Prod. 10(2), 262-268

[18] G. Iscan, N. Kirimer, M. Kurkcuoglu, T. Arabaci, E. Kupeli and K.H.C. Baser (2006). Biological activity and composition of the essential oils of Achillea schischkinii Sosn. and Achillea aleppica DC. subsp aleppica, J. Agr. Food Chem. 54(1), 170-173.

[19] A. Dadkhah, F. Fatemi, S. Ababzadeh, K. Roshanaei, M. Alipour and B.S. Tabrizi (2014). Potential preventive role of Iranian Achillea wilhelmsii C. Koch essential oils in acetaminophen-induced hepatotoxicity, Bot. Stud. 55:37. doi:10.1186/1999-3110-55-37

[20] S.Kordali, A. Cakir, T.A. Akcin, E. Mete, A. Akcin, T. Aydin and H. Kilic (2009). Antifungal and herbicidal properties of essential oils and n-hexane extracts of Achillea gypsicola Hub-Mor. and Achillea biebersteinii Afan. (Asteraceae), Ind. Crops \& Prod. 29(2/3),562-570.

[21] G. Benelli, S. Bedini, G. Flamini, F. Cosci, P.L. Cioni, S. Amira, F. Benchikh, H. Laouer, G. Di Giuseppe and B. Conti (2015). Mediterranean essential oils as effective weapons against the West Nile vector Culex pipiens and Echinostoma intermediate host Physella acuta: what happens around? An acute toxicity survey on nontarget mayflies, Parasit. Res. 114, 1011-1021.

[22] B. Conti, A. Canale, A. Bertoli, F. Gozzini and L. Pistelli (2010). Mediterranean aromatic plants against the mosquito Aedes allopictus (Diptera: Culicidae), Parasit. Res. 107, 1455-1461.

[23] C. Bicchi, C. Frattini, L. Cantamessa and L. Poggio (1988). On the composition of Achillea abrotanoides (Vis.) Vis. essential oil, Flav. Fragr. J. 3(3), 101-104.

[24] O. Toncer, S. Basbag, E. Diraz and M. Basbag (2010). Chemical composition of the essential oils of some Achillea species growing wild in Turkey, Int. J. Agric. Biol. 12(4), 527-530.

[25] N. Simic , R. Palic, V. Vajs, S. Milosavljevic and D. Djokovic (2002). Composition and antibacterial activity of Achillea asplenifolia essential oil, J. Essent. Oil Res. 14, 76-78.

[26] E.K. Akkol, U. Koca, I. Pesin and D. Yilmazer (2011). Evaluation of the wound healing potential of Achillea biebersteinii Afan. (Asteraceae) by in vivo excision and incision models, Evid-Based Compl Alt. 474026.

[27] Ö. Bariş, M. Gulluce, F. Sahin, H. Ozer, H. Kilic, H. Ozkan, M. Sokmen and T. Ozbek (2006). Biological activities of the essential oil and methanol extract of Achillea biebersteinii Afan. (Asteraceae), Turk. J. Biol. 30(2), 65-73.

[28] K. Polatoglu, O.C. Karakoc and N. Goren (2013). Phytotoxic, DPPH scavenging, insecticidal activities and essential oil composition of Achillea vermicularis, A. teretifolia and proposed chemotypes of A. biebersteinii (Asteraceae), Ind. Crop. Prod. 51, 35-45.

[29] R. Kotan, A. Cakir, F. Dadasoglu, T. Aydin, R. Cakmakci, H. Ozer, S. Kordali, E. Mete and N. Dikbas (2010). Antibacterial activities of essential oils and extracts of Turkish Achillea, Satureja and Thymus species against plant pathogenic bacteria, J. Sci. Food Agr. 90(1), 145-160.

[30] F.Z. Kucukbay, E. Kuyumcu and T. Arabaci (2010). The essential oil oil Achillea boissieri, Chem. Nat. Comp. 46(5), 824-825.

[31] N. Bezic, M. Skocibusic, V. Dunkic and A. Radonic (2003). Composition and antimicrobial activity of Achillea clavennae L. essential oil, Phytother. Res. 17(9), 1037-1040.

[32] Z. Boskovic, N. Radulovic and S. G. (2005). Essential oil composition of four Achillea species from the Balkans and its chemotaxonomic significance, Chem. Nat. Comp. 41(6), 674-678.

[33] E. Nemeth, B. J. and G. Tarjan (2008). Quantitative and qualitative studies of essential oils of Hungarian Achillea populations, J. Herbs, Spices \& Med. Pl. 13(1), 57-69.

[34] Z. Toker, H.C. Ozen, R.A. Clery and N.E. Owen (2003). Essential oils of two Achillea species from Turkey, J. Essent. Oil Res. 15(2), 100-101.

[35] F.Z. Kucukbay, E. Kuyumcu, T. Bilenler and B. Yildiz (2012). Chemical composition and antimicrobial activity of essential oil of Achillea cretica L. (Asteraceae) from Turkey, Nat. Prod. Res. 26(18), 1668-1675.

[36] A. Konakchiev, M. Todorova, B. Mikhova, A. Vitkova and H. Najdenski (2011). Composition and antimicrobial activity of Achillea distans essential oil., Nat. Prod. Comm. 6(6), 905-906.

[37] P. Weyerstahl, H. Marschall, I. Seelmann and A. Rustaiyan (1997). Constituents of the essential oil of Achillea eriophora DC., Flav. Fragr. J. 12, 71-78.

[38] M. Kurkcuoglu, B. Demirci, N. Tabanca, T. Ozek and K.H.C. Baser (2003). The essential oil of Achillea falcata L., Flav. Fragr. J. 18(3), 192-194. 
[39] F.Z. Kucukbay, E. Kuyumcu, S. Gunal and T. Arabaci (2011). Composition and antimicrobial activity of essential oil of Achillea formosa subsp. amanica, Chem. Nat. Comp. 47(2), 300-302.

[40] K.H.C. Baser, B. Demirci, H. Duman, Z. Aytac and N. Adiguzel (2001). Composition of the essential oil of Achillea goniocephala boiss. et bal. from Turkey, J. Essent. Oil Res. 13(4), 219-220.

[41] S. Kordali, A. Cakir, T.A. Akcin, E. Mete, A. Akcin, T. Aydin and H. Kilic (2009). Antifungal and herbicidal properties of essential oils and n-hexane extracts of Achillea gypsicola Hub-Mor. and Achillea biebersteinii Afan. (Asteraceae), Ind. Crop Prod. 29(2-3), 562-570.

[42] F.P. Turkmenoglu, O.T. Agar, G. Akaydın, M. Hayran and B. Demirci (2015). Characterization of volatile compounds of eleven Achillea species from Turkey and biological activities of essential oil and methanol extract of A. hamzaoglui Arabacı \& Budak, Molecules. 20(6), 11432-11458.

[43] K.H.C. Baser, B. Demirci and H. Duman (2001). Composition of the essential oils of two endemic species from Turkey: Achillea lycaonica and A. ketenoglui, Chem. Nat. Comp. 37(3), 245-252.

[44] A. Bader, L. Panizzi, P.L. Cioni and G. Flamini (2007). Achillea ligustica: composition and antimicrobial activity of essential oils from the leaves, flowers and some pure constituents. Cent. Eur. J. Biol. 2(2), 206-212.

[45] C.I.G. Tuberoso, A. Kowalczyk, V. Coroneo, M.T. Russo, S. Dessi and P. Cabras (2005). Chemical composition and antioxidant, antimicrobial, and antifungal activities of the essential oil of Achillea ligustica All., J. Agr. Food Chem. 53(26), 10148-10153.

[46] A.D. Azaz, T. Arabaci, M.K. Sangun and B. Yildiz (2008). Composition and the in vitro antimicrobial activities of the essential oils of Achillea wilhelmsii C. Koch. and Achillea lycaonica Boiss \& Heldr., As. J. Chem. 20(2), 1238-1244.

[47] V.K. Agnihotri, S.K. Lattoo, R.K. Thappa, P. Kaul, G.N. Qazi, A.K. Dhar, A. Saraf, B.K. Kapahi, R.K. Saxena and S.G. Agarwal (2005). Chemical variability in the essential oil components of Achillea millefolium Agg. from different Himalayan habitats (India), Planta Med. 71(3), 280-283.

[48] A. Barghamadi, M. Mehrdad, F. Sefidkon, Y. Yamini and M. Khajeh (2009). Comparison of the volatiles of Achillea millefolium L. obtained by supercritical carbon dioxide extraction and hydrodistillation methods, $J$. Essent. Oil Res. 21(3), 259-263.

[49] A. Kocak, E. Bagci and A. Bakoglu (2010). Chemical composition of essential oils of Achillea teretifolia Willd. and A. millefolium L. subsp millefolium growing in Turkey, As. J. Chem. 22(5), 3653-3658.

[50] S. Alinezhad, A. Kamalzadeh, M. Shams-Ghahfarokhi, M.B. Rezaee, K. Jaimand, M. Kawachi, Z. Zamani, R. Tolouei and M. Razzaghi-Abyaneh (2011). Search for novel antifungals from 49 indigenous medicinal plants: Foeniculum vulgare and Platycladus orientalis as strong inhibitors of aflatoxin production by Aspergillus parasiticus, Ann. Microbiol. 61, 673-681.

[51] F. Gogus, M.Z. Ozel and A.C. Lewis (2006). Extraction of essential oils of leaves and flowers of Achillea monocephala by superheated water, Flav. Fragr. J. 21(1), 122-128.

[52] C. Bekhechi, F.A. Bekkara, J. Casanova and F. Tomi (2011). Composition and antimicrobial activity of the essential oil of Achillea odorata L. subsp. pectinata (Lamk) var. microphylla (Willd.) Willk. from Northwestern Algeria, J. Essent. Oil Res. 23(3), 42-46.

[53] K.H.C. Baser, B. Demirci, R. Kaiser and H. Duman (2000). Composition of the essential oil of Achillea phrygia Boiss. et Ball, J. Essent. Oil Res. 12(3), 327-329.

[54] A. Akcin, T.A. Akcin, F. Seyis, A.Y. Coban and B. Durupinar (2014). Antimicrobial and antioxidant activity of the essential oil of the Turkish endemic species Achillea phrygia Boiss. \& Bal., J. Essent. Oil Bear. Pl. 17(2), 219-227.

[55] S. Albayrak (2013). The volatile compounds and bioactivity of Achillea sieheana Stapf. (Asteraceae), Iran J. Pharm. Res. 12(1), 37-45.

[56] N. Tabanca, T. Ozek, K.H.C. Baser and M. Vural (2004). Composition of the essential oil of Achillea sieheana stapf and the enantiomeric distribution of camphor, J. Essent. Oil Res. 16(3), 180-181.

[57] E. Donmez, B. Tepe, D. Daferera and M. Polissiou (2005). Composition of the essential oil of Achillea schischkinii Sosn. (Asteraceae) from Turkey, J. Essent. Oil Res. 17(5), 575-576.

[58] A. Sokmen, G. Vardar-Unlu, M. Polissiou, D. Daferera, M. Sokmen and E. Donmez (2003). Antimicrobial activity of essential oil and methanol extracts of Achillea sintenisii Hub. Mor. (Asteraceae), Phytother. Res. 17(9), 1005-1010.

[59] P. Magiatis, A.L. Skaltsounis, I. Chinou and S.A. Haroutounian (2002). Chemical composition and in-vitro antimicrobial activity of the essential oils of three Greek Achillea species, Zeitschrift Fur Naturforschung C-a J. Bioscie. 57(3-4), 287-290.

[60] S. Aslan, H. Evren, B. Konuklugil, I. Turkoglu and M. Kartal (2009). Essential oil composition of Achillea teretifolia from Turkey, Chem. Nat. Comp. 45(2), 274-275.

[61] S.M.H. Alfatemi, J.S. Rad, M.S. Rad, S. Mohsenzadeh and J.A.T. da Silva (2015). Chemical composition, antioxidant activity and in vitro antibacterial activity of Achillea wilhelmsii C. Koch essential oil on methicillin-susceptible and methicillin-resistant Staphylococcus aureus spp., 3 Biotech. 5(1), 39-44. 
[62] A. Çakir, H. Özer, T. Aydin, S. Kordali, A.T. Çavusoglu, T. Akçin, T. and A. Akçin (2016). Phytotoxic and insecticidal properties of essential oils and extracts of four Achillea species. Rec. Nat. Prod., 10(2), 154-167.

[63] M.R. Tellez, I.A. Khan, B.T. Schaneberg, S.L. Crockett, Rimando A.M. and M. Kobaisu (2004). Steam distillation-solid-phase microextraction for the detection of Ephedra sinica in herbal preparations, $J$. Chromatogr. A. 1025, 51-56

[64] G. Özek, T. Özek and K.H.C. Baser (2006). Comparision of the essential oils of Prangos turcica A. Duran, M. Sağıroğlu et H. Duman fruits obtained by different isolation techniques, J. Essent. Oil Res. 18, 511-514.

[65] T. Özek, G. Özek and K.H.C. Baser (2005). Comparision of the essential oils of three endemic Turkish Heracleum species obtained by different isolation techniques, J. Essent. Oil Res. 17, 605-610.

[66] G. Özek, F. Demirci, T. Özek, N. Tabanca, D.E. Wedge, S.I. Khan, K.H.C. Başer, A. Duran and E. Hamzaoglu (2010). Gas chromatographic-mass spectrometric analysis of volatiles obtained by four different techniques from Salvia rosifolia Sm., and evaluation for biological activity, J. Chromatogr. A. 1217(5), 741-748.

[67] T. Özek, G. Özek, K. Baser and A. Duran (2005). Comparison of the essential oils of three endemic Turkish Heracleum species obtained by different isolation techniques, J. Essent. Oil Res. 17(6), 605-610.

[68] G. Özek, T. Özek, K. Başer, A. Duran, M. Sagiroglu and H. Duman (2006). Comparison of the essential oils of Prangos turcica A. Duran, M. Sagiroglu et H. Duman fruits obtained by different isolation techniques, J. Essent. Oil Res. 18(5), 511-514.

[69] G. Özek, T. Özek, K. Baser, A. Duran and M. Sagiroglu (2006). Comparison of essential oil of Xanthogalum purpurascens Lallem. obtained via different isolation techniques, J. Essent. Oil Res. 18(2), 181-184.

[70] T. Özek, G. Özek, K.H.C. Başer, A. Duran and M. Sagiroglu (2008). Composition of the essential oils of Angelica sylvestris L. var. sylvestris isolated from the fruits by different isolation techniques, J. Essent. Oil Res. 20(5), 408-411.

[71] W.A. König, R. Krebber, P. Evers and G. Bruhn (1990). Stereochemical analysis of constituents of essential oils and flavor compounds by enantioselective capillary gas chromatography, J. Sep. Scie. 13(5), 328-332.

[72] K. Oosterhaven, K. Hartmans and J. Scheffer (1995). Inhibition of potato sprout growth by carvone enantiomers and their bioconversion in sprouts, Potato Res. 38(2), 219-230.

[73] A.K. Tripathi, V. Prajapati and S. Kumar (2003). Bioactivities of 1-carvone, d-carvone, and dihydrocarvone toward three stored product beetles, J. Econ. Entomol. 96(5), 1594-1601.

[74] EDQM (2005). Determination of Essential Oils in Vegetable Drugs. European Pharmacopea 5.0. Vol. 1. European Directorate for the Quality of Medicines. Strasburg: 217-218.

[75] J. Folch, M. Lees and S. G.H.S. (1957). A simple method for the isolation and purification of total lipides from animal tissues, J. Biol. Chem. 226, 497-509.

[76] W.R. Morrison and L.M. Smith (1964). Preparation of fatty acid methyl esters and dimethylacetals from lipids with boron fluoride-methanol, J. Lipid Res. 5(4), 600-608.

[77] I.A. Schepetkin, S.V. Kushnarenko, G. Özek, L.N. Kirpotina, P. Sinharoy, G.A. Utegenova, K.T. Abidkulova, T. Özek, K.H. Baser and A.R. Kovrizhina (2016). Modulation of human neutrophil responses by the essential oils from Ferula akitschkensis and their constituents, J. Agr. Food Chem. 64(38), 7156-7170.

[78] D. Joulain, W.A. König and D.H. Hochmuth (2001). Library of MassFinder-4, in Terpenoids and related constituents of essential oils, D.H. Hochmuth, Editor. Hochmuth Scientific Consulting: Hamburgh, Germany.

[79] R.P. Adams (1995). Identification of Essential Oil Components By Gaz Chromatography/Mass Spectroscopy. Allured Publishing Corporation. Carol Stream.

[80] K.H.C. Baser and F. Demirci (2007). Chemistry of Essential Oils, in Flavours and Fragrances. Chemistry, Bioprocessing and Sustainability, R.F. Berger, Editor. Springer-Verlag: Berlin, Heidelberg. p. 43-83.

[81] H. Noorizadeh, A. Farmany and M. Noorizadeh (2011). Application of GA-PLS and GA-KPLS calculations for the prediction of the retention indices of essential oils, Química Nova. 34(8), 1398-1404.

[82] A. Maggio, S. Rosselli, M. Bruno, V. Spadaro, F.M. Raimondo and F. Senatore (2012). Chemical composition of essential oil from Italian populations of Artemisia alba Turra (Asteraceae), Molecules. 17(9), 10232-10241.

[83] D. Rigano, M. Marrelli, C. Formisano, F. Menichini, F. Senatore, M. Bruno and F. Conforti (2017). Phytochemical profile of three Ballota species essential oils and evaluation of the effects on human cancer cells, Nat. Prod. Res. 31(4), 436-444.

[84] J.J. Brophy, R.J. Goldsack, A. Punruckvong, A.R. Bean, P.I. Forster, B.J. Lepschi, J.C. Doran and A.C. Rozefelds (2000). Leaf essential oils of the genus Leptospermum (Myrtaceae) in eastern Australia. Part 7. Leptospermum petersonii, L. liversidgei and allies, Flav.Fragr. J. 15(5), 342-351.

[85] H. Noorizadeh and A. Farmany (2010). Exploration of linear and nonlinear modeling techniques to predict of retention index of essential oils, J. Chinese Chem. Soc. 57(6), 1268-1277.

[86] A. Mangia and M. Careri (2001). Gas chromatography-mass spectrometry analysis of flavors and fragrances, in Current Practice of Gas Chromatography-Mass Spectrometry. CRC Press. p. 409-440.

[87] C. Bignell, P. Dunlop and J. Brophy (1998). Volatile leaf oils of some south-western and southern Australian species of the genus Eucalyptus (series 1). Part XIX, Flav. Fragr. J. 13(2), 131-139. 
[88] J. Palá-Paúl, J. Brophy, R. Goldsack and B. Fontaniella (2004). Analysis of the volatile components of Lavandula canariensis (L.) Mill., a Canary Islands endemic species, growing in Australia, Biochem. Syst. Ecol. 32(1), 55-62.

[89] A. Orav (2001). Identification of terpenes by gas chromatography-mass spectrometry, in Current Practice of Gas Chromatography-Mass Spectrometry. CRC Press. p. 483-494.

[90] E. Mancini, L. De Martino, A. Marandino, M.R. Scognamiglio and V. De Feo (2011). Chemical composition and possible in vitro phytotoxic activity of Helichrsyum italicum (Roth) Don ssp. italicum, Molecules 16(9), $7725-7735$.

[91] T. Aşkun, K.H.C. Başer, G. Tümen and M. Kürkçüoğlu (2010). Characterization of essential oils of some Salvia species and their antimycobacterial activities, Turk. J. Biol. 34(1), 89-95.

[92] F. Ayaz, N. Küçükboyacı and B. Demirci (2017). Chemical composition and antimicrobial activity of the essential oil of Conyza canadensis (L.) Cronquist from Turkey, J. Essent. Oil Res., 29(4), 336-343.

[93] R. Tabacchi, G. Saturnin, C. Porret, M. Biedermann, S. Sponsler and L. Bitzer (1997). Guide to the analysis of chiral compounds by GC, Restek Corp. Lit. Cat.\#59889

[94] J.J. Filippi, D.A. Lanfranchi, S. Prado, N. Baldovini and U.J. Meierhenrich (2006). Composition, enantiomeric distribution, and antibacterial activity of the essential oil of Achillea ligustica All. from Corsica, J. Agr. Food Chem. 54(17), 6308-6313.

[95] A. Ertaş, M. Boğa, N. Haşimi, Y. Yeşil, A.C. Gören, G. Topçu and U. Kolak (2014). Antioxidant, anticholinesterase, and antimicrobial activities and fatty acid constituents of Achillea cappadocica Hausskn. et Bornm, Turk. J. Chem. 38(4), 592-599.

[96] F.A. Ayaz, H. Inceer, S. Hayirlioglu-Ayaz and N. Aksu-Kalmuk (2016). Achene fatty acid composition in the Tribe Anthemideae (Asteraceae), Rom. Biotechnol. Lett. 21(3), 11576-11584.

[97] D. Warner, S.K. Jensen, J.W. Cone and A. Elgersma (2010). Fatty acid composition of forage species. in the 23rd General Meeting of the European grassland Federation. Kiel, Germany Organising Committee of the 23th General Meeting of the European Grassland Federation

[98] R. Palić, G. Stojanović, N. Ranđelović, V. Ranđelović and J. Veličković (2000). The fatty acids from plants of the genus Achillea, Facta universitatis-series: Physics, Chem. Technol. 2(2), 101-104.

[99] S.A.H. Goli, M. Rahimmalek and B.E.S. Tabatabaei (2008). Physicochemical characteristics and fatty acid profile of yarrow (Achillea tenuifolia) seed oil, Int. J. Agr. Biol. 10, 355-357.

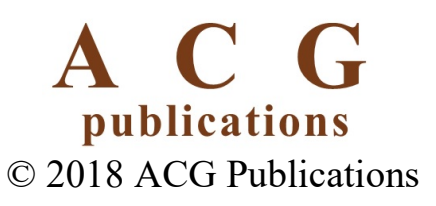

